\title{
Det fleirkulturelle perspektivet i grunnskolelærarutdanningane
}

\author{
Av Knut Duesund og Åsmund AamaAs
}

The article focuses on multicultural education in the Norwegian teacher education programs. We ask to what extent the student teachers experience achieving relevant competence. The findings indicate that the student teachers are relatively satisfied with the competence and skills they achieve. However, they ask for more specific knowledge about the pupils' religious and cultural background. Knowledge about these factors could, according to the student teachers, be given through a compulsory element in the curriculum focusing on religion and culture. The findings seem to be in accordance with other researches which show that multicultural competence requires that the teachers have knowledge about the cultural background of the different minority groups. On the other hand, it seems like the students are not to any great extent aware that minority students tend to be overrepresented in special education and compensatory actions in schools. This finding indicates that there is a need for putting more emphasis on critical thinking with regards to multiculturalism in the teacher education programs in Norway, and an analytical approach in this context.

Keywords: teacher education, multicultural education, critical multiculturalism, religion, culture, Banks

$$
\begin{aligned}
& \text { KNUT DUESUND, (F. 1950). Førstelektor Høgskolen i Telemark, Lererskolev. 40, } 3679 \text { Notodden. } \\
& \text { E-post: knut.duesund@hit.no }
\end{aligned}
$$

Åsmund AAMAAS, (F. 1978). Høgskolelektor Høgskolen i Telemark, Larrerskolev. 40, 3679 Notodden. E-post: asmund.aam-

$$
\text { aas@hit.no }
$$

\section{INNLEIING}

«Vi har riktignok hatt om det flerkulturelle samfunnet [... men jeg mener at vi kunne og burde hatt enda mer om dette temaet. Det er jo ikke alle studentene som velger RLE som valgfag. Innsikt i andre kulturer og religioner skaper ...] større forutsetninger for å kunne legge til rette for et godt samarbeid både med elev og foreldre ...» Dette skriv ein av studentane i ei undersøking om fleirkulturell kompetanse i lærarutdanningane. Svaret fangar opp nokre av dei mest interessante funna som blir presentert og drøfta i denne artikkelen.

Lærarutdanninga skal mellom anna tilpassast eit aukande sosialt, språkleg, religiøst og kulturelt mangfald i Noreg. Innvandring har bidrege til denne utviklinga, og i 2013 hadde 12,8 prosent av elevane i grunnskulepliktig alder innvandrarbakgrunn (Utdanningsdirektoratet, 2013). Denne situasjonen har stilt myndigheiter, utdanningsinstitusjonar og lærarar overfor nye moglegheiter og utfordringar. I norsk lærarutdanningkom detfleirkulturelleperspektivet for alvor inn med ny rammeplan i 1999. Dette kom som ei fylgje av ny rammeplan i grunnskulen to år tidlegare der kristendomskunnskap med religionsog livssynsorientering (KRL) vart innført som obligatorisk fag. KRL skulle både gje innsikt og byggja bruer. Det skulle bidra til respekt og dialog på tvers av trus- og livssynsgrenser og fremja 
forståing og toleranse i religiøse og moralske spørsmål. I lærarutdanninga vart dette fylgd opp ved at KRL der og vart gjort til eit obligatorisk fag (Kirke-, utdannings- og forskningsdepartementet, 1999:73).

Det blei raskt strid om grunnskulefaget KRL. Dette førte til rettsprosessar både nasjonalt og internasjonalt. Læreplanane har blitt endra fleire gonger, sist i 2008, og faget er no vidareført som religion, livssyn og etikk (RLE) som er obligatorisk i grunnskulen (sjå Lied, 2009:263276). I lærarutdanninga har det vore ei litt anna utvikling. Faget er endra og heiter RLE der og, men er ikkje obligatorisk i dei nye grunnskulelærarutdanningane (GLU) som blei innført i 2010 (Kunnskapsdepartementet, 2010a). Dermed har ikkje RLE ei særskilt rolle i GLU som eit fag som skal utvikla kompetanse til å hjelpa elevane med ulik bakgrunn til identitetsutvikling, og bidra til toleranse og dialog mellom menneske med ulik livsoppfatning, slik KRL-faget skulle (jf. Kirke-, utdannings- og forskningsdepartementet, 1999:76). Etter retningslinjene for GLU har det obligatoriske emnet pedagogikk og elevkunnskap (PEL) delvis overteke denne funksjonen og har fått eit særskilt ansvar for å ivareta det fleirkulturelle perspektivet. Samstundes er dette perspektivet vektlagt i den generelle delen av dei nasjonale retningslinjene, og det skal vera eit gjennomgåande tema i alle delar av utdanningane.

I den generelle delen av retningslinjene for GLU heiter det at dei framtidige lærarane skal ha kunnskap om og forståing for det fleirkulturelle samfunnet. Dei skal ha kjennskap til kulturelle skilnader, til menneskerettane og til rettane til urfolk. Det heiter at ei global, internasjonal og fleirkulturell orientering skal prega utdanningane. Etter PEL-planen er det krav om at studenten skal utvikla ferdigheiter til å arbeida med elevar med ulik bakgrunn. Lærarstudentane skal ha kunnskap om sosialt, språkleg, religiøst og kulturelt mangfald og gjennom det bli sett i stand til å støtta elevane si læring i ein inkluderande skule prega av dialog og respekt for den enkelte. Studenten sitt læringsutbyte skal omfatta forståing av kva dei unike personlege, sosiale og kulturelle føresetnadene har å seia for læringa. Dette skal fylgjast opp i praksisopplæringa, og særleg i praksisperiodane $\mathrm{i}$ det andre studieåret skal elevmangfaldet, lærararbeid og læringsleiing i det fleirkulturelle klasserommet vera eit hovudtema (Kunnskapsdepartementet, 2010b:9-30).

Lærarutdanningsinstitusjonane som skal fylgja opp dette og implementera retningslinjene, har ifylgje melding til Stortinget 6 (2012-13) varierande kunnskap på dette feltet (Barne-, likestillings- og inkluderingsdepartementet, 2012). Fylgjegruppa som evaluerer GLU, har sett på faglærarar sin kompetanse innanfor fleirkulturelle perspektiv og korleis dette kjem til uttrykk i utdanningane. Hovudinntrykka deira var at alle studentane ved dei seks institusjonane dei besøkte, hadde arbeidd noko med tematikken. Samtidig gjev fylgjegruppa som si tilråding at faglærarane må få høve til å setja seg betre inn i forskrifta sine krav til fleirkulturell kompetanse. Dei skriv og at «Institusjonane bør sørgje for systematiske ordningar for å sikre at studentane arbeider med undervisning i fleirkulturelle klasserom.» (Kunnskapsdepartementet, 2013: 75). Det synest dermed å vera ei utfordring å få implementert det fleirkulturelle perspektivet i samsvar med krava i GLU. Ei særleg utfordring i denne samanhengen er ifylgje Thor Ola Engen at majoritetsperspektivet kan komma til å dominera opplæringa (Dyndahl, Engen, \& Kulbrandstad, 2011:17). Thor-André Skrefsrud hevdar at ein slik dominans kan føra til «en skjult kulturell assimilering ikledd en flerkulturell retorikk.» (Skrefsrud, 2013:277).

Dette viser at det er behov for meir kunnskap om korleis det fleirkulturelle perspektivet blir implementertiGLU, ogdenneartikkelensernærare på dette. Utgangspunkt er i ei spørjeundersøking 
frå våren 2013 der tredjeårs-studentar ved begge grunnskulelærarutdanningane ved fem universitet og høgskular i Sør-Noreg vart invitert til å uttala seg. ${ }^{1}$ Målet med undersøkinga var å undersøkja fylgjande: Gjev lærarutdanninga tilfredsstillande fleirkulturell kompetanse - sett frå eit studentsynspunkt?

Før vi går nærare inn på resultata frå undersøkinga og kommenterer dei, er det naudsynt å sjå på kva som blir forstått med omgrepet fleirkulturell kompetanse.

\section{FLEIRKULTURELL KOMPETANSE}

Den amerikanske forskaren James Banks har fått stort gjennomslag med sine teoriar om fleirkulturell opplæring og kompetanse. Han har utvikla eit program som han meiner kan fungera som eit utgangspunkt for fleirkulturell opplæring i skulane, men og som eit teoretisk rammeverk i forsking. Programmet hans byggjer på fem dimensjonar eller kriterier som han hevdar må takast omsyn til om opplæringa skal lukkast. Han kallar desse kriteria for «dimensions of multicultural education $\gg$.Den første dimensjonen kallar han «content integration». Dette fokuserer på læraren sin bruk av eksempel og materiale frå eit mangfald av kulturar. Vidare har han med «knowledge construction», som dreiar seg om korleis implisitte kulturelle faktorar påverkar kunnskapsdanninga. Ein tredje dimensjon er «prejudice reduction» som handlar om korleis undervisninga kan modifisera fordommar. Ein fjerde dimensjon er det han kallar «equity pedagogy». Dette handlar om ein pedagogikk som organiserer undervisninga slik at den fremjar prestasjonane hjå elevar med ulik kulturell bakgrunn. Den femte og siste dimensjonen i teorien hans er «empowering school culture» og handlar om eit læringsmiljø som fokuserer på respekt og likeverd. Dei fem dimensjonane må sjåast i samanheng og verka saman om ein skal lukkast med ei fleirkulturell opplæring, ifylgje Banks (Banks, 2009:1 og 15-17).

Det kulturelle perspektivet som er sentralt i Banks teori, synest å ha vunne innpass $\mathrm{i}$ retningslinjene for GLU. Der heiter det at $\ll$... Lærere må ha kunnskap om og forståelse for det flerkulturelle samfunn. Det innebærer oppmerksomhet om kulturelle forskjeller, og ferdigheter til å håndtere disse som en positiv ressurs.» (Kunnskapsdepartementet, 2010b:9). Det same gjeld Kunnskapsdepartementet si forståing av fleirkulturell skule og barnehage i strategiplanen «Likeverdig opplæring i praksis» der det heiter at det fleirkulturelle og språklege mangfaldet er ein normaltilstand som skal nyttast som ein ressurs av lærarane (Kunnskapsdepartementet, 2007:9). Ressursperspektivet er og framheva i Melding til Stortinget 20 (2012-2013) om kvalitet og mangfald i fellesskolen. Kva som ligg i omgrepa normaltilstand og ressurs er ikkje konkretisert eller problematisert i desse dokumenta, slik at dette må gjerast til gjenstand for tolking (jf. Westrheim \& Tolo, 2014:115). Likefullt må ein kunna tolka dette som føringar som skal liggja til grunn for all utdanning i Noreg, inkludert lærarutdanningane.

Sjølv om det fleirkulturelle perspektivet er innarbeidd i retningslinjene, vil det truleg vera ei utfordring å få dette implementert i lærarutdanninga. Ifylgje Michael Hillis har det til dømes i amerikanske lærarutdanningar vore ein trengsel om plassen og vanskeleg å implementera nye element i utdanningane, blant anna kurs som skulle gje fleirkulturell kompetanse (Hillis, 1998). Theo Koritzinsky har i ein analyse av læreplanutvikling vist at dette også er utfordrande i ein norsk kontekst. Han skriv at det er krevjande «å følge opp nytt/og / eller utvidet lærestoff i

1 Forfattarane takkar Høgskolen i Oslo og Akershus og dei andre fire institusjonane som har bidrege med verdifull hjelp, slik at vi kunne nå ut til studentane og samla inn data til undersøkinga som denne artikkelen byggjer på. 
læreplaner» med tanke på «kvalifiserte lærere, etterutdanning, egnete læremidler og tilstrekkelig timetall» (Koritzinsky, 2006:38).

Ei særleg utfordring i denne samanhengen er å gjere det fleirkulturelle perspektivet til noko meir enn språkopplæring. I skule og lærarutdanning har språkopplæring dominert både nasjonalt og internasjonalt (sjå, t.d., Lemaire, Alidou og Kong i Banks, 2009:2009:23, 330-331, 392-394 og 50350). Banks omtalar dette som språkparadigmet, og han framhevar at fokuset på språk har vist seg å komma til kort. Språk må sjåast på som ein integrert del av kulturen og vera ein av fleire faktorar som blir vektlagt i opplæringsplanar (Banks, 2009:23-24). Joron Pihl hevdar at dette sterke fokuset på språkopplæring i det norske utdanningssystemet, inkludert lærarutdanninga, viser at den fleirkulturelle pedagogikken ikkje er basert på empiriske fakta. Skulen som er prega av språkleg og kulturell kompleksitet, legg opp undervisninga som om alle elevane har norsk språkleg og kulturell bakgrunn (Pihl, 2010:214). Pihl og fleire andre har peika på at dersom dette skjer, kan utdanninga få ein monokulturell og assimilerande karakter (sjå bl.a. Banks, 2009; Dyndahl et al., 2011:17). Pihl viser i si forsking at ei følgje av den manglande verdsetjing av den kulturelle bakgrunnen er at minoritetselevane er overrepresenterte i kompensatoriske og spesialpedagogiske tiltak i den norske skulen. Den fleirkulturelle pedagogikken må etter hennar syn ta omsyn til kulturbakgrunnen og leggja vekt på samanhengen mellom heim og skule i tråd med dei tankane Anton Hoëm lanserte i Noreg allereie på 1970-talet (Pihl, 2010:19-22, 193-203, og 268274). Hoëm tok utgangspunkt i utfordringane samiske barn møtte i møtet med den norske skulen, ein skule tilpassa majoritetskulturen og med lærarar utan tilstrekkelege føresetnader for å gje alle elevane like moglegheiter til læring (Hoëm, 1978:36-44).

Med dette som bakteppe skal vi sjå på kva synspunkt studentane hadde på implementeringa av det fleirkulturelle perspektivet i GLU.

\section{METODE OG FORSKINGSMATE- RIALE}

Studiet som er grunnlag for denne artikkelen, byggjer på ei spørjeundersøking. Data blei samla inn ved hjelp av eit elektronisk spørjeskjema frå QuestBack. Skjemaet vi nytta, hadde 22 spørsmål. 16 spørsmål var formulert som påstandar der studentane skulle velja eit av fem svaralternativ: heilt ueinig, ganske ueinig, verken einig eller ueinig, ganske einig eller heilt einig. Spørsmåla var laga med utgangspunkt i retningslinjene for GLU 1.-7. og 5.-10. trinn. Vi tok utgangspunkt i det som står om det fleirkulturelle perspektivet i den generelle delen av planen og det som står om dette i planen for PEL-faget. Spørsmåla omfatta haldningar, synet på lærarutdanninga og vurderingar av eigne kunnskapar og ferdigheiter i forhold til fleirkulturell opplæring. To spørsmål var opne og gav studentane høve til frie tekstsvar. Tanken var at desse svara kunne gje oss informasjon som var vanskeleg å fanga opp med strukturerte spørsmål. I analysen av tekstsvara nytta me analyseverktyet NVivo.

Utvalet vårt bestod av tredjeårsstudentane $\mathrm{i}$ GLU 1.-7. trinn og 5.-10. trinn ved fem universitet og høgskular i Sør-Noreg våren 2013. Dei fem institusjonane blei valt ut frå to kriterium. Det eine var at utvalet skulle representera ein relativt stor del av den totale populasjonen. Talet på studentar ved dei fem institusjonane var 640, og dette utgjer i overkant av 40 prosent av dei om lag 1550 studentane på dette trinnet våren 2013 (Kunnskapsdepartementet, 2013). Det andre kriteriet var at institusjonane som vi vende oss til, skulle vera lokalisert både i urbane og mindre urbane kontekstar. Det ville dermed vera sannsynleg at faglærarane, praksisskulane og studentane hadde ulik grad av erfaring med fleirkulturell opplæring. 
Det kom inn 155 svar (N) som gjev ein svarprosent på 23,25 \% av utvalet vårt, og som utgjer ganske nøyaktig $10 \%$ av det nasjonale studenttalet på det tredje årstrinnet våren 2013 . Den relativt låge deltakinga kan ha vore påverka av at tidspunktet kolliderte med ein praksisperiode ved ein av institusjonane. I tillegg veit vi at studentane som begynte lærarutdanninga i 2010 har vore mål for mykje fylgjeforsking, og det er sannsynleg at den generelle svarprosenten er påverka av dette. Svarprosent har sjølvsagt innverknad på korleis ein kan bruka resultata. Vår relativt låge svarprosent fører til at vi ikkje kan trekkje bastante konklusjonar om det fleirkulturelle perspektivet i lærarutdanningane på grunnlag av denne undersøkinga. Like fullt kan ein trekkje konklusjonar om kva dei 155 som har svart, meiner. I denne samanhengen blir tekstsvara særleg interessante. Tekstsvara representerer 155 studentar sine tankar om det fleirkulturelle, og er dermed gyldig kunnskap om kva dei forbind med ein fleirkulturell skule, og kva dei meiner kan gjerast for å få betre fram det fleirkulturelle aspektet i lærarutdanninga og i praksisopplæringa. Det er derfor naturleg å leggja stor vekt på tekstsvara i presentasjonen av funna våre.

\section{FUNN}

I det fylgjande trekkjer vi fram funna i undersøkinga, og begynner med kva studentane forbind med omgrepet «ein fleirkulturell skule».

\section{Fleirkulturell skule}

Studentane fekk først eit opent spørsmål der dei kunne svara fritt i eit tekstfelt. Spørsmålet var «Hva tenker du på når du hører uttrykket en flerkulturell skole?» Formålet med spørsmålet var å finna ut om det er ei samanfallande forståing av dette uttrykket eller om det er ulike oppfatningar og nyansar. Vi ville og undersøke om den forståinga av fleirkulturell opplæring som vi i dag finn i forskingsmiljø, hadde slått inn i utdanninga.
Tendensane i svara kan delast inn i ulike hovudkategoriar, men fleirtalet av svara kan passa inn i meir enn ein av desse kategoriane. Dette kan eksemplifiserast gjennom følgjande skildring av kva ein fleirkulturell skule er:

ressursorientert, men likevel bevisst utfordringene, jobber for forståelse og dialog, åpenhet om forskjellene, ulike kulturer både i personalet og $i$ elev-ogforeldregruppen, ser kultur ikke bare som et geografisk/nasjonalt/religiøst fenomen, anser seg selv som og profilerer seg som en «flerkulturell skole» (respondent 7)

Dei to første kategoriane vi identifiserte i analysen var utfordringar og moglegheiter. 76 svar kan etter denne inndelinga kategoriserast som ressursorienterte eller fokusert på moglegheiter, medan 22 var problemorienterte eller fokusert på utfordringar. Dei resterande svara kan kategoriserast som nøytrale. I gruppa som fokuserer på moglegheiter, dominerer beskrivande svar der ein legg vekt på å bruke mangfaldet som ein ressurs. Svara her inneheld positivt lada ord som at det er gøy, men også meir didaktiske responsar som at den fleirkulturelle skulen er ressursorientert der ein $\ll .$. . ser på flerkulturen som en ressurs i skolehverdagen» (respondent 15). Når det gjeld utfordringar, seier fire av dei 22 at det er utfordrande med samarbeid med foreldre, medan ytterlegare fem peikar på ulike forventningar som ei utfordring. Det er 14 som slår fast at det er utfordringar i forhold til den fleirkulturelle skulen utan å spesifisere dette noko vidare.

Ein annan kategori vi identifiserte var knytt opp mot innvandring som tema. Dette blei nemnt av 63 respondentar. Respondentane i denne kategorien nemnde eksplisitt ein eller fleire av dei fylgjande faktorane: land, nasjonalitetar, etnisitet, minoritet og utsjånad. Døme på svar i denne kategorien var «barn fra andre land» (respondent 109), «elever av ulik nasjonalitet, ...» (respondent 131) og det meir samansette 
svaret «ikke bare kulturer knyttet til andre land, men også f.eks bykultur, bondekultur og andre typer kulturer» (respondent 87). Dei to fyrste sitata viser eit tydeleg fokus på det fleirkulturelle som knytt opp mot landegrenser. I det siste sitatet kjem det og fram at respondenten opererer med skilnader innan majoritetsbefolkninga, og at den fleirkulturelle skulen ikkje automatisk skal knytast opp mot innvandring. Innvandring blir elles sjeldan nemnt eksplisitt. Seks respondentar brukte dette ordet for å skildra den fleirkulturelle skulen. 12 av respondentane viste til utsjånad og ein til rase. Utsjånad må i denne samanhengen knytast opp mot geografisk bakgrunn. Eit av svara her var truleg ironisk meint: «At man i utgangspunktet må ha en annen hudfarge enn majoriteten, det er det vi lærer, og at man helst bør ha opplevd noe traumatisk» (respondent 38).

Ein fjerde hovudkategori vi fann, var ein definisjonsdebatt. Fire studentar skriv at omgrepet fleirkulturell ikkje er det beste utgangspunktet for å arbeide med mangfald i den norske skulen. Det blir argumentert for at ein felleskulturell skule er eit betre utgangspunkt enn fleirkulturell. Ein av respondentane skriv at ein fleirkulturell skule er

Det motsatte av en felleskulturell skole. En flerkulturell skole oppfatter jeg som en skole bestående av flere kulturer, men at dette er en utfordring, og at det ikke passer inn i et ferdiglaget system. En felleskulturell skole derimot, omfavner alle, og bruker kulturen som ressurs. (respondent 146).

Ei overraskande side ved funna våre var at forholdsvis få studentar nemnde språkopplæring og spesialpedagogikk som vi innleiingsvis hevda har hatt ein sentral plass i fleirkulturell opplæring. Språkopplæring og utfordringar knytt opp mot dette blir rett nok nemnt i 32 av svara. Spesialpedagogikk blir berre nemnt av to av studentane. Dette tyder på at studentane ikkje opplever den fleirkulturelle opplæringa først og fremst som eit problem, men slik vi har sett, er mange opptekne av moglegheiter og framhevar mangfaldet som ein ressurs.

Den mest omfattande kategorien er kultur. Om lag halvparten, 76 respondentar, nemner dette ordet. Kultur blir i mange tilfelle sidestilt med språk og religion, berre unntaksvis blir kultur utdjupa, og då gjerne i forhold til kulturelle uttrykk som klede. Berre ein student nemner kulturrelativisme. Kategorien religion blir nemnt av 45 studentar, og er altså nemnt oftare enn både språk og spesialpedagogikk.

Etter denne gjennomgangen skal vi sjå på nokre av funna i den kvantitative delen av undersøkinga. I denne delen blei studentane bedne om å ta stilling til ulike påstandar.

\section{Kulturell bakgrunn}

Studentane blei fyrst bedne om å ta stilling til påstanden «Min egen kulturelle bakgrunn vil påvirke undervisningen min». Studentane er ganske samde om at deira eigen kulturbakgrunn vil påverka undervisninga. Diagrammet i figur 1 viser korleis svara fordeler seg på dei fem svaralternativa.

$69,1 \%$ av studentane svarer at dei er ganske eller heilt einige i at deira eigen kulturelle bakgrunn kan påverke undervisninga. ${ }^{2}$ På påstanden $\ll$ Det vil være vanskelig å være lærer hvis jeg får elever med minoritetsbakgrunn i klassen» svarer eit stort fleirtal av studentane at dette ikkje vil vera

\footnotetext{
2 «Verken einig eller ueinig»-kategorien utgjer ein relativt stor prosentdel i mange av svara, i nokre tilfelle mellom 20 og $30 \%$. Vi har valt ikkje å gå nærare inn på denne kategorien i analysen fordi det alltid vil vera svært usikkert kvifor respondentane har valt denne svarkategorien. Baka, Figgou og Triga, t.d., meiner ut frå sine studiar at respondentar vel denne kategorien når dei manglar kunnskap om temaet eller når dei er likegyldige. Eit anna alternativ er at dei vel kategorien fordi spørsmålet representerer eit vanskeleg dilemma og respondentane opplever ambivalens (Baka, Figgou, \& Triga, 2012). Dersom det er slike grunnar som ligg bak når våre respondentar svarer «verken eller», kan det tyda på at mange av studentane ikkje har blitt eksponert for det fleirkulturelle perspektivet i undervisning og praksisperiodar. Det kan på den andre sida ha si årsak i at dei opplever tematikken som krevjande og løyser dilemmaet ved å kryssa av for «verken einig eller ueinig».
} 


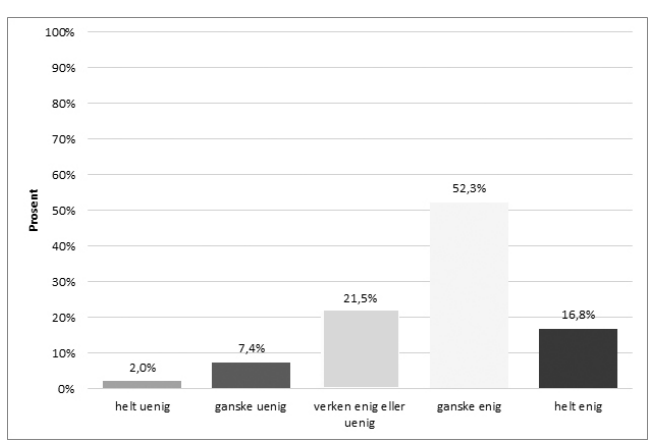

Figur 1. Påstand: «Min egen kulturelle bakgrunn vil påvirke undervisningen min»

tilfelle. $77,7 \%$ svarer at dei er heilt ueinige eller ganske ueinige i denne påstanden. Studentane er og nærmast eintydige i svaret på påstanden om at «Elever med ulik kulturell og religiøs bakgrunn i klassen min vil være en ressurs i undervisningen», jf. figur 2. Her seier 89,7 \% seg heilt eller ganske einige $i$ at slike elevar vil vera ein ressurs i undervisninga. Når ein ser på resultata frå kvar enkelt institusjon, viser det seg at det og er liten sprik mellom studentane ved dei ulike institusjonane i forhold til dei nemnde påstandane. Samla viser denne gruppa med spørsmål at studentane er bevisste om at både deira eigen bakgrunn og elevane sin bakgrunn spelar ei rolle i skulen.

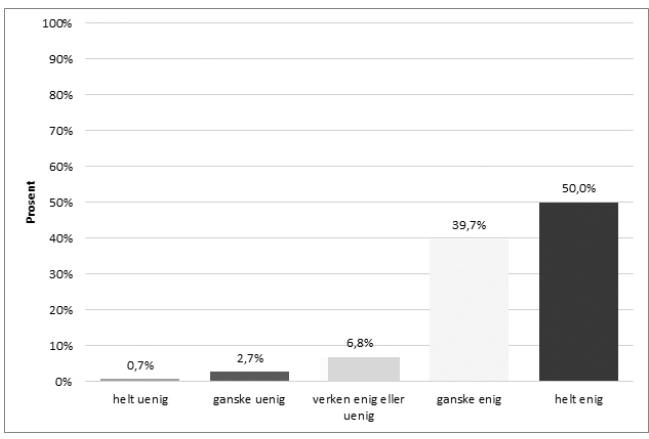

Figur 2. Påstand: «Elever med ulik kulturell og religiøs bakgrunn i klassen min vil være en ressurs i undervisningen.»

\section{Vurderinga av eigen kompetanse}

Fem av spørsmåla bad studentane vurdere eigen kunnskap og kompetanse med tanke på arbeid i ein fleirkulturell skule. Resultata viser at dei aller fleste studentane meiner at dei vil vera i stand til å gjennomføra undervisninga på ein god måte, og mange meiner dei har god kompetanse på dette feltet. På spørsmål om dei føler seg «i stand til å få elever med ulik kulturell og religiøs bakgrunn til å arbeide godt saman» svarer $85,5 \%$ at dei er ganske eller heilt einige slik figur 3 viser. Det er ingen som er heilt ueinige og berre $0,7 \%$ som er ganske ueinige i dette.

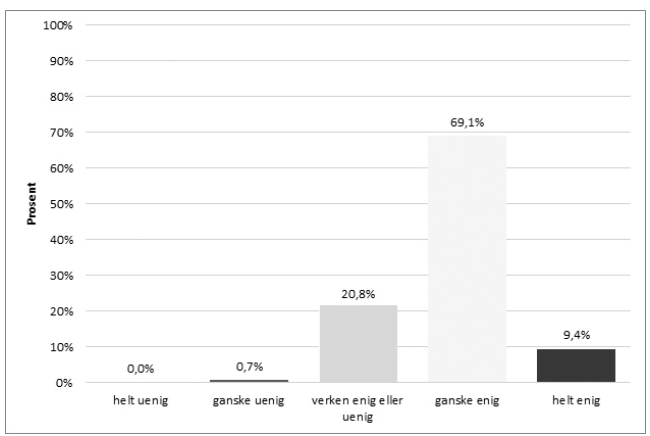

Figur 3. Påstand: «Jeg vil være i stand til å få elever med ulik kulturell og religiøs bakgrunn til å arbeide godt sammen.»

Når det gjeld teoretisk kunnskap om kulturelle og religiøse minoritetar, ser resultata noko annleis ut. Studentane blei bedne om å ta stilling til påstanden «Jeg har god kunnskap om de ulike kulturelle og religiøse minoritetene i Norge». Her viser det seg at $26,9 \%$ er heilt eller ganske ueinige i at dei har god kunnskap om dette, slik figur 4 viser. $50,3 \%$ svarer at dei er heilt eller ganske einige i at dei har god kunnskap. Svaret på denne påstanden må ein sjå i samanheng med tekstsvara i slutten av undersøkinga der studentane kunne komma med forslag til forbetringar av GLU. Der trekkjer mange studentar, som vi skal sjå, fram at dei har behov for meir kunnskap om det religiøse og kulturelle mangfaldet. 


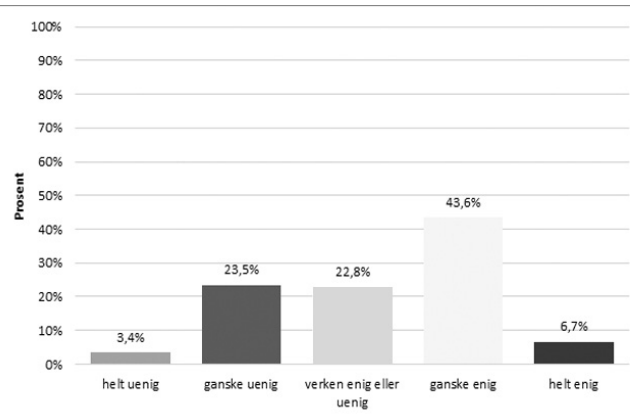

Figur 4. Påstand: «Jeg har god kunnskap om de ulike kulturelle og religiøse minoritetene i Norge.»

\section{Fleirkulturell kompetanse gjennom lærarutdanningane}

Retningslinjene for grunnskolelærarutdanninga var utgangspunkt for ei gruppe påstandar om kva kunnskap og kompetanse studentane hadde fått med seg gjennom utdanninga. Alle påstandane her var formulert med utgangspunkt i punkt 3.2 i retningslinjene, som handlar om innhaldet i utdanningane og blant anna seier kva som er viktige element i forhold til det fleirkulturelle perspektivet (jf. retningslinjene, Kunnskapsdepartementet, 2010a:9).

Studentane er mest nøgd med utdanninga når dei svarer på påstanden «Lærerutdanningen har gitt meg kunnskap om og innsikt i det flerkulturelle samfunnet». Slik figur 5 viser, svarer $55 \%$ at dei er heilt einige eller ganske einige i dette, medan $21,4 \%$ seier at dei er ganske ueinige eller heilt ueinige. Når det derimot gjeld påstanden om at «Lærerutdanningen har gitt meg kunnskap om og innsikt i elevenes ulike kulturelle og religiøse bakgrunn», er det ei relativt stor gruppe som meiner at utdanningane i liten grad har gjeve dei dette. Slik figur 6 viser, seier 33,1 $\%$ av respondentane at dei er heilt eller ganske ueinige i at utdanninga har gjeve slik kunnskap og innsikt. 41, 3 \% seier at dei er ganske einige eller heilt einige $i$ at utdanning gjev slik kunnskap og innsikt. Resultatet på dette punktet samsvarer berre delvis med det studentane svarte om sin eigen kompetanse, som er referert ovanfor, og det dei skriv om behovet for meir kompetanse om religion og kultur i det opne tekstsvaret til slutt i undersøkinga. Sjølv om dette resultatet viser at mange studentar ser behov for meir kunnskap, er det likevel fleire som er tilfreds med utdanninga på dette punktet enn dei som er misnøgde. Skilnaden mellom den kvalitative og kvantitative delen av undersøkinga gjer det vanskeleg å konkludera på dette punktet. Det vi kan seia, er at studentane synest å ha ulikt syn på om utdanninga gjev dei tilfredsstillande fleirkulturell kompetanse.

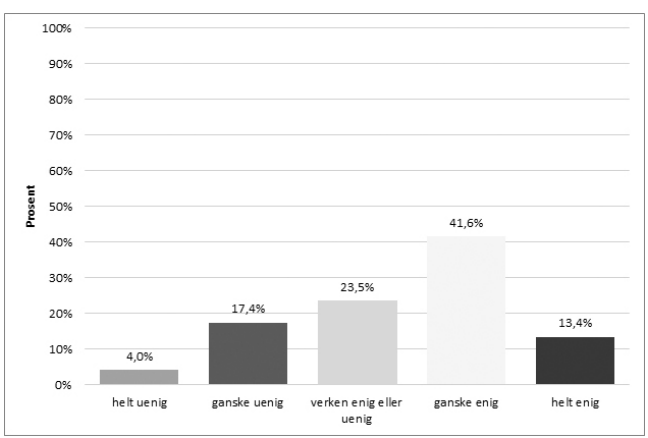

Figur 5. Påstand: «Lærerutdanningen har gitt meg kunnskap om og innsikt i det flerkulturelle samfunnet.»

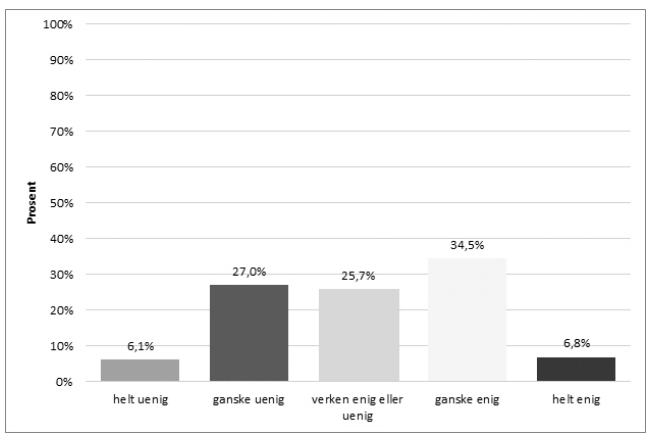

Figur 6. Påstand: «Lærerutdanningen har gitt meg kunnskap om og innsikt i elevenes ulike kulturelle og religiøse bakgrunn»

Når det gjeld påstanden om at «Lærerutdanningen har gitt meg kunnskap om og innsikt 
i menneskerettighetene $\gg$, seier $57,7 \%$ at dei er ganske eller heilt einige. Eit område relativt mange studentane meiner lærarutdanninga har gjeve liten kunnskap om og innsikt i, er globalt fredsarbeid og internasjonal forståing. 44, 6 \% er heilt eller ganske ueinige i at lærarutdanninga har gjeve dette. Berre $27,7 \%$ svarer ganske eller heilt einige $i$ at utdanninga har gjeve denne kunnskapen og innsikta som dei etter retningslinjene skulle ha tileigna seg. Slik figur 7 viser, seier $49,6 \%$ at dei er heilt eller ganske einige $i$ at dei gjennom utdanninga har fått ferdigheiter til å arbeida med tema dialog og toleranse, medan 21,1 $\%$ svarer at dei er heilt eller ganske ueinige i dette. Det viser at om lag ein femdel av studentane meiner dei ikkje har utvikla kompetanse på dette feltet.

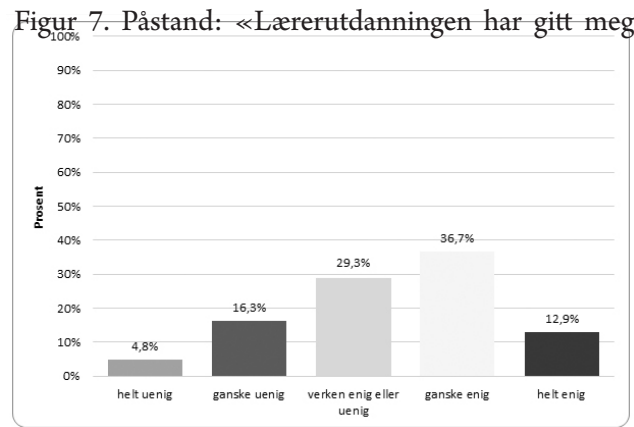

ferdigheter til å arbeide med temaene dialog og toleranse»

\section{Tiltak som kan forbetra lærarutdanningane}

Til slutt i undersøkinga blei studentane bedne om å uttala seg om kva som kunne forbetrast i lærarutdanningane. Fylgjande formulering blei brukt:

Til slutt ber vi om at du med noen få stikkord forteller hva du eventuelt mener bør forbedres i larerutdanningen for å gi framtidige lererne bedre forutsetninger for å arbeide i en flerkulturell skole, gjerne med kommentarer om følgende forhold: Rammeplaner/fagplaner for larerutdanningen, aktiviteter og praksis.
I tekstsvara nemner mange studentar praksis. Nokre skriv at dei er nøgde med den praksisen dei har hatt, men svært mange peikar på at dei treng meir praksis. «Teoretiske forelesninger gir lite innenfor dette faget», skriv ein (respondent 36). Det blir framheva at dei i tillegg til meir praksisnær undervisning treng meir praksis i klasserom med minoritetselevar. Mange av kommentarane indikerer at studentane ikkje har hatt praksis i det dei forstår som ein fleirkulturell skule. Ein skriv følgjande: «Nå på tredje året har jeg fortsatt medstudenter som ikke har vært i annet enn blendahvite klasserom der de aldri markerer FN-dagen.» (respondent 6). Ein annan meiner det er altfor tilfeldig korleis studentane blir plassert i praksisperiodane. Fleire meiner at praksis i ein fleirkulturell skule skulle ha vore obligatorisk. Det synest dermed som om studentane ikkje kjenner til at praksis $\mathrm{i}$ det andre studieåret $\mathrm{i}$ GLU skal ha eit hovudfokus på elevmangfald og lærararbeid i det fleirkulturelle klasserommet (sjå retningslinjene, Kunnskapsdepartementet, 2010a:25). Det er dermed grunn til å spørja om kor godt retningslinjene for praksis i GLU har blitt implementert på lærarutdanningsinstitusjonane.

Studentane er og kritiske til måten det fleirkulturelle stoffet blir behandla på i teoriundervisninga. Dei hevdar det er uklar bruk av omgrep, som fleirkulturell, framandspråkleg, minoritetsspråkleg og fleire andre omgrep. Vidare meiner mange at det er for lite praksisnær undervisning og bruk av konkrete eksempel. Fleire foreslår trening i konfliktløysing. Det kan og synast som om studentane opplever at det er manglande erfaring frå praksisområdet hjå forelesarane. Dette kunne ha vore kompensert ved å trekkja inn lærarar frå praksisområdet i teoriundervisninga, blir det hevda. «Lærerutdanningen er for teoretisk, den største utfordringen er å få mer didaktikk, og praktiske eksempler og oppgaver inn i forelesningene.» heiter det i eit svar (respondent 32). 
Det mest overraskande funnet i tekstsvara er det sterke fokuset på kunnskap om religionar og kultur. I 20 av svara blir meir kunnskap om religionar og kulturar nemnt som ein nødvendig føresetnad for å gjera lærarutdanninga betre. I tillegg til dei 20 som nemner meir kunnskap om religionar og kulturar, er det 22 som eksplisitt nemner faget «Religion, livssyn og etikk» (RLE). Dette er overraskande, sidan det ikkje er noko i den innleiande teksten eller spørsmåla studentane fekk, som nemner RLE-faget. Spørsmåla refererer berre til den generelle delen av retningslinjene eller bruker uttrykk som er henta frå PELplanen der uttrykka kulturelt, sosialt og religiøst mangfald er brukt. Mange studentar er tydelege på at kunnskap om religionar og kulturar burde bli obligatorisk i lærarutdanninga. Nokre peikar på at slik kunnskap burde tydeleg inn i PEL-faget, medan fleirtalet av dei som nemner RLE-faget, tek til orde for at faget burde ha blitt gjort obligatorisk. Dette standpunktet blir særleg grunngjeve ved å vise til eiga erfaring. Studentar som har teke RLE som valfag, hevdar at utan den kunnskapen som dette faget har gjeve, ville dei ikkje hatt føresetnad for å arbeida i ein fleirkulturell skule og ta hand om minoritetselevar med ulik religiøs og kulturell bakgrunn. Fylgjande utdrag får godt fram det fleire er inne på:

... så føler jeg at jeg har relativt god kompetanse på disse områdene fordi jeg har hatt RLE (valgfag). Der larte vi masse om hvordan man kan legge opp undervisning med tanke på elever med ulik religiøs tilknytning. Vi hadde mye om dialog, toleranse og respekt. Vi har riktignok hatt om det flerkulturelle samfunnet i PEL (obligatorisk for GLU), men jeg mener at vi kunne og burde hatt enda mer om dette temaet. Det er jo $i k k e$ alle studentene som velger RLE som valgfag. Innsikt $i$ andre kulturer og religioner skaper forståelse og toleranse også hos lareren og større forutsetninger for å kunne legge til rette for et godt samarbeid både med elev og foreldre. [... Jeg føler at mye av det jeg har leert $i$ RLE og Norsk fordypning burde vert en del av det obligatoriske lopet $i$ GLU....] (respondent 66)

\section{OPPSUMMERING OG DRØFTING}

Funna vi har presentert ovanfor, har vist at dei 155 studentane som svarte, ikkje har ei eintydig forståing av omgrepet fleirkulturell skule. Dette tyder på at studentane har ulike bilete av kva oppgåver dei skal bli kvalifisert for, og kva som trengst for å ha det vi har kalla fleirkulturell kompetanse. Lærarutdanningsmiljøa kan derfor ha eit behov for å klargjera korleis dei tolkar det fleirkulturelle perspektivet $\mathrm{i}$ retningslinjene for GLU. Samstundes viser funna at studentane i stor grad er nøgde med sin eigen kompetanse og eigne ferdigheiter i forhold til å arbeida i ein fleirkulturell skulekontekst. Dei er og relativt godt nøgde med den kompetansen lærarutdanninga har gjeve dei, men etterlyser samstundes meir praksisnær undervisning og relevant praksis i fleirkulturelle klasserom. Studentane etterlyser spesielt meir kunnskap om kulturar og religionar.

\section{Eit kritisk blikk}

Eit overraskande funn i undersøkinga er at svært få studentar nemner spesialpedagogikk i samband med fleirkulturell kompetanse. Det kan dermed sjå ut til at den forskinga som dokumenterer at minoritetselevar er overrepresentert i spesialundervisning, ikkje er godt kjent blant studentane (jf. Pihl, 2010:19-22). Heller ikkje det som Banks omtalar som språkparadigmet, har så stor plass som ein kunne ha venta. Det er berre ein femdel av studentane som har nemnt norskopplæring i tekstsvara sine. Studentane synleggjer dermed i liten grad at dei har kunnskap om det omfanget kompensatorisk undervisning og spesialpedagogiske tiltak har hatt. Dette tyder på at desse forholda er underkommunisert i den norske lærarutdanninga, og at det er for lite kritisk blikk på den etablerte praksisen i den norske skulen. 
Eit slikt kritisk blikk må ifylgje Banks inkludera kunnskap om kvifor mange minoritetsgrupper er offer for institusjonell rasisme og klasseskilnader (Banks, 2006:95). Stephen May framhevar vidare at både lærarar og lærarstudentar må forstå dei kommunikative utfordringane som oppstår når elevane og lærarane har ulike identitetar (sjå May i Banks, 2009:44). Dette er og sentralt i kritisk multikulturalisme. Her ligg vekta på ein strukturell analyse av ulike maktforhold, blant anna at institusjonaliserte skilnader kan vera resultat av historiske prosessar og rådande diskursar $\mathrm{i}$ skulen og samfunnet elles, med dei negative utslaga dette kan få for minoritetselevar (May \& Sleeter, 2010:10). Overført til GLU kan dette innby til større vektlegging av kritisk analyse og debatt omkring systematiske forskjellar langs etniske skiljeliner i klasserommet, til å drøfta reproduksjon av sosial ulikskap gjennom utdanningssystemet og kva forklaringsmodellar som kan liggja bak.

\section{Ressursperspektivet}

Det som må kunna kallast eit positivt funn i forhold til den rådande diskursen om den fleirkulturelle skulen, er det fokuset studentane synest å ha på eit ressursperspektiv. Dermed synest det som om den forskinga som ser på elevane sin kulturelle bakgrunn som ein ressurs, har blitt kommunisert til studentane. Konkret såg vi at om lag halvparten av studentane assosierte ein fleirkulturell skule med moglegheiter og såg pluralisme som ein ressurs då dei svarte på det innleiande opne spørsmålet i undersøkinga. Dette kjem klart og fram både i den kvalitative og i den kvantitative delen av undersøkinga. Som figur 2 viser, sa $89,7 \%$ av studentane at dei er heilt eller ganske einige $i$ at elevar med ulik kulturell eller religiøs bakgrunn vil vera ein ressurs for undervisninga. Ei slik vektlegging er i tråd med intensjonane i retningslinjene for GLU, og må sjåast som eit konstruktivt utgangspunkt i møte med ein fleirkulturell skulekvardag. Sjølv om Banks og andre teoretikarar ikkje blir nemnde av studentane, er det tydeleg at dei gjennom lærarutdanninga eller gjennom annan påverknad er prega av ei tenking som er på linje med Banks teoriar på dette punktet.

Som vi har sett, er ressursperspektivet noko blant anna Hoëm og Banks ser som ein føresetnad for å lukkast med fleirkulturell opplæring. Hoëm legg spesielt vekt på at læringa berre kan lukkast dersom elevane opplever samanheng mellom sin eigen kulturbakgrunn og skulen sin læringskultur (Hoëm, 1978:62-64). Han seier at det er nødvendig at «tilpasningen finner sted både på samfunnsnivå (utdanningspolitisk nivå), på institusjonsnivå (skolenivå) og på individnivå» (Pihl, 2010:270). Banks fokuserer på at undervisninga må organiserast slik at den fremjar prestasjonar uavhengig av kulturell bakgrunn, og at det må skapast eit læringsmiljø som legg vekt på respekt og likeverd. Det er viktig å sjå på kvar enkelt elev, med sin unike bakgrunn, som ein ressurs. Læringsprosessen må ta utgangspunkt $i$ at dei implisitte kulturelle faktorane påverkar kunnskapsdanninga, og at ein derfor både må kjenna og ta omsyn til desse (Banks, 2009:1516). John Hattie hevdar at det å akseptere at elevane kjem til skulen med ulik type kulturarv, er det same som å verdsetja bakgrunnen deira, og eit grunnlag for å utnytta dette i læringsprosessen. Hattie meiner at han på grunnlag av metaanalyser kan påvisa ein slik samanheng. Han hevdar at «Det ser virkelig ut til å være svært verdifullt å opprettholde et positivt syn på egen kulturell bakgrunn» og at dette har effekt på læring (Hattie \& Goveia, 2013:101-103).

\section{Mangfald blant lærarane}

Ein forhold som kan vera vesentleg for å forstå korleis dei kulturelle faktorane påverkar læringa, er lærarane sin eigen kulturelle bakgrunn. 69,1\% av studentane $i$ vår undersøking svarer at dei er 
ganske eller heilt einige i at deira eigen kulturelle bakgrunn vil kunna påverka undervisninga. Vi tematiserte ikkje studentane sin bakgrunn i undersøkinga, men det er sannsynleg at dei fleste har bakgrunn i majoritetsbefolkninga. Dei siste ti åra har talet på lærarstudentar med innvandrarbakgrunn berre lege på 3-4 \%. (Statistisk sentralbyrå, 2014). Dermed reflekterer rekrutteringa til læraryrket ikkje samansetjinga av elevmassen.

Antoinette Gagné peikar, slik Hoëm tidlegare har gjort, på at læraren sin kulturelle bakgrunn vil kunna verka inn på evna til å forstå elevane og til å byggja bru mellom skule og minoritetsforeldre. Ho konkluderer med at dette krev at ein arbeider for å rekruttera personar med innvandrarbakgrunn til læraryrket (Ringen, Kjørven, \& Gagné, 2009:71-72). Eit mangfald blant lærarar og i skuleleiinga kan truleg bidra til å lukkast betre med fleirkulturell opplæring (jf. Nieto in Banks, 2009:89; Westrheim \& Tolo, 2014:48). Eit slikt mangfald ville kunne gje elevane rollemodellar med ulik kulturell bakgrunn, og lærarar som har betre føresetnader for å forstå korleis kunnskapsdanninga skjer i dei ulike kulturane (Ringen et al., 2009:72).

\section{Kunnskap om kulturar og religionar} I tillegg til eit positivt syn på den kulturelle bakgrunnen, synes konkret kunnskap om kulturar og religionar å ha mykje å seia for ei vellukka fleirkulturell opplæring. Banks peikar på at kunnskap om kulturar vil kunne hjelpa læraren til bruk av eksempel og materiale frå eit mangfald av kulturar og til ei undervisning som modifiserer fordommar (Banks, 2009:15-16). Slik vi såg, etterlyste studentane i vår undersøking nettopp meir konkret kunnskap om kulturar og religionar. Dette var særleg synleg i det siste spørsmålet i undersøkinga der studentane vart bedt om å komme med forslag til forbetringar av lærarutdanningane. Her skriv mange respondentar at dei treng større kunnskap om kulturar og religionar, og mange peiker på at RLE derfor burde ha vore eit obligatorisk fag i utdanningane. Behovet for meir konkret kunnskap har og kome fram i andre undersøkingar. I ei OECD-undersøking frå 2008 svarte nærare 60 prosent av dei norske ungdomsskolelærarane at dei hadde lite eller ikkje noko behov for fagleg oppdatering i å undervise i eit multikulturelt miljø, men paradoksalt nok visast det i same rapport til at svært mange skular har behov for kompetanse og formalkunnskap på dette feltet (Vibe, Aamodt, \& Carlsten, 2009:5253 og 68). Den same diskrepansen kjem til syne i ei undersøking blant nyutdanna lærarar i USA frå 2008. $76 \%$ av utvalet svarte at fleirkulturell opplæring hadde vore med i utdanninga deira, men likevel svarte over halvparten at dei ikkje kjende seg godt nok førebudde til å undervise elevar med ulik bakgrunn (Nieto i Banks, 2009:89).

Eit sentralt poeng i denne samanhengen er at den konkrete kunnskapen som etterspørjast, ikkje må formidlast slik at det fører til ei kulturell essensialisering. Ein tanke om uforanderlege essensar, som utelet kva rolle historisk forankra forskjellar spelar, vil komma til kort. Eit fokus på kultur og identitet som uforanderlege og stabile einingar kan føre til stereotypifisering og fordommar snarare enn fleirkulturell kompetanse. Grunnskulelærarstudentane må bli kjent med at kulturell utveksling gjer at identitetar er i stadig endring og at det oppstår nye hybride identitetar (sjå May i Banks, 2009:44; Østberg, 2003:101104).

\section{Eit multifaktor-paradigme}

Vår undersøking tyder på at mange av dei vesentlege faktorane som må vera til stades for å gje ein god fleirkulturell kompetanse, er i ferd med å få plass i den nye lærarutdanninga. Samstundes er det behov for ei vidare utvikling, men slik Banks framhevar, kan ein ikkje utvikla ein fleirkulturell kompetanse berre gjennom å 
tilføra lærar og lærarstudentar kunnskapar og ferdigheiter og utvikla gode haldningar. Det er det samla skulemiljøet som er mest avgjerande for læringsprosessen. Det teoretiske rammeverket Banks har presentert, og som vi har hatt som ein hovudreferanse, må oppfattast som ein heilskap. Det må vera ein interaksjon mellom dei fem dimensjonane. Fleirkulturell opplæring er eit komplisert prosjekt, og det er behov for eit multifaktor-paradigme. Ifylgje Banks utgjer kvar skule ein mikrokultur, og målet må ikkje vera ei assimilering inn i majoritetskulturen, som historisk har vore det vanlege, men eit prosjekt som har kulturmøte, kulturutveksling og interaksjon som mål (Banks, 2009:15-32).

\section{VEGEN VIDARE}

Utgangspunktet for vårt prosjekt har vore å auke kunnskapen om den fleirkulturelle kompetansen lærarutdanningane gjev, for i neste omgang å kunna bruka denne forskinga for å utvikla og tilpassa utdanningane på dette sentrale området. I denne samanhengen kan det vere relevant å trekkja inn forsking om implementering av nye element i lærarutdanningar frå USA. Her viser to faktorar seg å vere avgjerande. For det fyrste er det avgjerande at teoriundervisninga legg vekt på det aktuelle aspektet, og for det andre er det naudsynt at lærarstudentane blir eksponert for dette området når dei er i praksisopphald på skular (DarlingHammond \& Lieberman, 2012:138-143). Dette samsvarer godt med det vi har sett i studiet vårt. Lærarstudentar etterspør kunnskap om religionar og kulturar, praksisnær undervisning og meir medviten bruk av praksisskular i forhold til fleirkulturell kompetanse. Dette bør lyttast til i vidareutvikling av lærarutdanningane på dette området.

Ei side av GLU-utdanningane som bør bli gjenstand for drøfting, er den delen som gjeld dei ulike faga i lærarutdanningane. Med unntak av norsk, som berre er obligatorisk for GLU 1.-7. trinn, og valfaga samfunnsfag og RLE, er det fleirkulturelle perspektivet i liten grad teke inn i kunnskapsdelen av retningslinjene for dei andre faga. Den avmålte plassen det fleirkulturelle perspektivet har fått, representerer ei utfordring i høve til å gje studentane god fleirkulturell kompetanse.

Med tanke på tiltak som kan styrkja fleirkulturell kompetanse, syner studiet vårt at det i tillegg til praksisnær undervisning først og fremst er ei kritisk analyse av minoritetane sin plass i skulesystemet og kunnskap om religionar og kulturar som bør får større rom. Konkret kan dette gjerast ved at RLE blir gjort obligatorisk slik mange av respondentane foreslår. Eit anna alternativ kan vera å gjera samfunnsfag obligatorisk. Mykje av den kunnskapen om kultur og minoritetar som studentane etterlyser, ville truleg ha kunna blitt dekka gjennom dette faget. Eit tredje alternativ kunne vera å styrkja PELplanen på dette området, til dømes ved å leggja inn ein eigen modul med desse elementa, slik at både religionsfaglege og samfunnsfaglege emne fekk større plass i PEL-faget. Eit fjerde alternativ vil vera å involvere fagpersonar og litteratur frå dei to faga i sterkare grad i sjølve implementeringa av denne delen av utdanninga. I tillegg er det behov for å trekkja inn det fleirkulturelle perspektivet $\mathrm{i}$ retningslinjene for alle faga i lærarutdanningane.

\section{LITTERATUR}

Baka, A., Figgou, L., \& Triga, V. (2012). 'Neither agree, nor disagree': A critical analysis of the middle answer category in Voting Advice Applications. International Journal of Electronic Governance, 5(3/4), 244-263. doi: 10.1504/ IJEG.2012.051306

Banks, J.A. (2006). Race, culture, and education: The selected works of James A. Banks. London: Routledge.

Banks, J. A. (Red.). (2009). The Routledge international companion to multicultural education. New York: Routledge. 
Darling-Hammond, L., \& Lieberman, A. (Red.). (2012). Teacher education around the world: Changing policies and practices. London: Routledge.

Dyndahl, P., Engen, T. O., \& Kulbrandstad, L. I. (Red.). (2011). Lcererutdanningsfag, forskning og forskerutdanning: Bidrag til kunnskapsområder $i$ endring. Vallset: Oplandske bokforlag.

Hattie, J. (2013). Synlig lering for laerere: Maksimal effekt på laring. Oslo: Cappelen Damm akademisk.

Hillis, M. R. (1998). What is the Role of Cultural Diversity in the Teacher Education Curriculum. Journal of Research in Education, 8(1), 43-47.

Hoëm, A. (1978). Sosialisering: En teoretiskog empirisk modellutvikling. Oslo: Universitetsforlaget.

Kirke, utdannings- og forsknings-departementet. (1999). Rammeplan og forskrift for 4-årig allmennlcererutdanning. Oslo: Norgesnettrådet.

Kjørven, O. K., Ringen, B.-K., \& Gagné, A. (Red.). (2009). Teacher diversity in diverse schools: Challenges and opportunities for teacher education. Vallset: Oplandske bokforlag.

Koritzinsky, T. (2006). Samfunnskunnskap: Fagdidaktisk innføring (2. utg.). Oslo: Universitetsforlaget.

Kunnskapsdepartementet. (2007). Likeverdig opplaring i praksis! Strategi for bedre lcering og storre deltakelse av språklige minoriteter $i$ barnehage, skole og utdanning 2007-2009. Hentet fra http://www.regjeringen.no/upload/KD/ Vedlegg/Grunnskole/Strategiplaner/UDIR Likeverdig_opplaering2_07.pdf

Kunnskapsdepartementet. (2010). Forskrift om rammeplan for grunnskole-lcererutdanningene for 1.-7. trinn og 5.-10. trinn. Hentet fra http://www.regjeringen.no/upload/KD/ Rundskriv/2010/Forskrift_rammeplan_ grunnskolelaererutdanningene.pdf.

Kunnskapsdepartementet. (2010). Nasjonale retningslinjerforgrunnskolelærerutdanningene. Hentet fra http://www.regjeringen.no/nb/ dep/kd/dok/lover_regler/retningslinjer /2010/nasjonale-retningslinjer-forgrunnskolel.html?regj_oss=1\&id=640249.

Lied, S. (2009). The Norwegian Christianity, Religion and Philosophy subject KRL in Strasbourg. British Journal of Religious Education, 31(3), 263-275. doi: $10.1080 / 01416200903112474$

May, S., \& Sleeter, C. E. (Red.). (2010). Critical multiculturalism: Theory and praxis. New York: Routledge.

Meld. St nr. 6 2012-2013. (2012). En helhetlig integreringspolitikk. Mangfold og fellesskap. [Oslo]: Barne-, likestillings- og inkluderingsdepartementet. Hentet fra http://www. regjeringen.no/nb/dep/bld/dok/regpubl/ stmeld/2012-2013/meld-st-6-20122013. html?id=705945.

Pihl, J. (2010). Etnisk mangfold i skolen: Det sakkyndige blikket (2. utg.). Oslo: Universitetsforlaget.

Rogne, M., Lie, S. S., Malmo, K.-A. S., \& Munthe, E. (2013). Drivkraft i utviklinga av lærarprofesjonen? Rapport 3 fra følgegruppen for lærerutdanningsreformen.

Skrefsrud, T.-A. (2013). Det flerkulturelle som forsvant - tilbakeblikk på en rammeplanprosess. Prismet, 64(4), 267-279.

Utdanningsdirektotatet. (2013). Utdanningsspeilet 2013. Hentet fra http://www. udir.no/Tilstand/Utdannings-speilet/ Utdanningsspeilet/Utdanningsspeilet-2013/ Vibe, N., Aamodt, P. O., \& Carlsten, T. C. (2009). A vere ungdomsskolelerer $i$ Norge: resultater fra OECDs internasjonale studie av undervisning og laring (TALIS) (Vol. 23/2009). Oslo: NIFU STEP.

Westrheim, K., \& Tolo, A. (2014). Kompetanse for mangfold: Om skolens utfordringer $i$ det flerkulturelle Norge. Bergen: Fagbokforlaget.

Østberg, S. (2003). Muslim i Norge: Religion og hverdagsliv blant unge norsk-pakistanere. Oslo: Universitetsforlaget. 